\title{
Din ve Milliyetçik İlişkisi: Kolaylaştırıcı mı Zorlaştırıcı mi?
}

DOI: $10.26466 /$ opus. 864887

\author{
$\underline{\text { Halime Kökce* }}$ \\ * Dr. Öğr. Üyesi, İstanbul Sabahattin Zaim Üniversitesi (İZ̈̈), Sosyoloji Bölümü \\ İstanbul/Türkiye \\ E-Posta: karakashalime@gmail.com \\ ORCID: $0000-0003-2478-0497$
}

\begin{abstract}
Öz
Milliyetçiliğin doğuşundan itibaren dinler ve milliyetçilikler birbirleriyle ilişkili olarak gündeme gelmiştir. Tarih boyunca milliyetçilikler ya kendilerini dine karşı konumlandırmış ya da dinden güç almışlardır. Bu makalede, din ve milliyetçilik arasındaki ilişki tarihsel ve güncel örnekler üzerinden tartışılacaktır. Bu bağlamda, dinlerin milliyetçilikleri beslediği ve milliyetçiliğin dinin yerine geçtiği örnekler ele alınmıştır. Bunun yanı sıra dinin milli kimliğin oluşumuna engel teşkil ettiği örnekler de söz konusudur. Ya da tam tersine dinin etnik kimliğin belirginleşmesine, toplumun geri kalanından kendisini farklılaştırmasına yardımcı olduğu durumlar üzerinde de durulmuştur. Bu örnekler göz önüne alındığında aşağıdaki çıkarımı yapmak mümkün gözükmektedir. Din ve milliyetçilik arasında, ilerlemeci bakış açısının ürettiği türden tek tip bir ilişki yoktur. Modern Aydınlanmacı tezlerin aksine dinler, milliyetçilikler içinde çok güçlü damarlar olarak var olmaya devam edebilmektedir. Bu anlamda milliyetçiliğin din ile ilişkisi kurucu niteliktedir. Dinler, milliyetçilikler için vazgeçilmezdir. Dinin milliyetçiliği beslendiği durumlarda da bu böyledir; dinin arkaik, gerici ve milliyetçiliğin önünde engel olarak tasvir edildiği durumlarda da.
\end{abstract}

Anahtar Kelimeler: Din, milliyetçilik, etnik kimlik. 


\title{
The Relationship between Religion and Nationalism: Is it Facilitating or Complicating?
}

\begin{abstract}
Since the birth of nationalism, religion and nationalism have been a subject of debates in which they intertwine. Nationalists have either positioned themselves against religion or used religion as a tool in order to gain power throughout history. It is aimed, in this study, to discuss the relationship between religion and nationalism focusing on historical and contemporary cases. In this regard, the examples in which religion feed nationalism and nationalism replaces religion are reviewed. In addition to that, the instances, which reveal that religion sometimes hinders creation of national identity, is examined in this study, while, on the other hand, it is also shown that there are experiences in which religion becomes a bearing factor for development of ethnic identity and appearance of fractions within the society. By taking into consideration the occurrences in question, we can infer that there is not just one type of relationship between religion and nationalism, by contrast with the common acceptance which is a result of the generation of the perspective of the progressivists. Counter to the modern era Enlightenment theses, religion is able to continue to exist in a nationalist ideology as a strong core. In this sense, the relation of nationalism with religion plays a founding role. Religion is indispensable for nationalism. That's the way it goes in the cases either when religion is depicted as archaic, reactionary and seen as an obstacle to nationalism, or where nationalism is fed by religion.
\end{abstract}

Keywords: Involuntary migration, Syrians, border cities, social acceptance, cohesion 


\section{Giriş}

Milliyetçilik ve din ilişkisi, sosyal alana hükmeden ilişki biçimleri arasında belki de en çetrefilli, birbirini en dışlayıcı ve aynı zamanda birbirini en iyi tamamlayan ilişki biçimi olarak ele alınabilir. Yaygın görüş, modern anlamda milliyetçiliğin ortaya çıkmasıyla birlikte dinin güç kaybetmeye başladığı şeklindedir. Batı Avrupa tecrübesi bu tezi doğrular mahiyettedir. Bunun yanında, milliyetçiliğin dini yadsıdığı ya da dinden boşalan alanı ikame ettiği görüşü kadar din ve milliyetçiliğin birbirini beslediği görüşünü destekleyen örnekler de çokça mevcuttur. Balkan milliyetçiliklerinde olduğu gibi.

Rasyonel akıl hakim oldukça dinin hayattan çekilip gideceği tezi bir zamanlar aydınlanma ve pozitivizm düşüncesinin kendinden emin tezleriyken bugün artık dinin hiçbir şekilde yok olup gitmediği bilakis tüm görünürlügü̈yle toplumsal ve siyasal hayatı belirleyebilecek güçte olduğu bilinmektedir. Özellikle Avrupa'da sanayileşmenin ortaya çıkışıyla birlikte Hıristiyan dinine karşı yükselişe geçen inkar ve inançsızlığın yol açtığı boşluğa dikkat çekilmekte ve bu boşluğun da milliyetçilik ve komünizm gibi düşüncelerle ikame edildiği öne sürülmektedir. Milliyetçiliğin dini ikame edici fonksiyonunu öne çıartanlar milliyetçiliğin Hıristiyani kökenlerine vurgu yapmakta ve toplumun ihtiyaç duyduğu dindarane hissi karşıladığını ileri sürmektedirler (Hayes, 1995). Bu bakış açısında milliyetçilik adeta laik devletin kutsallaştırılmasıdır. Fransız Devrimi ile birlikte hakim olan milliyetçilik tam da bunu temsil ediyordu. Vatan, akıl, özgürlük gibi soyut kavramlar kutsallaştırılmış, dini ritüellerin bir benzeri olarak, bayramlar, ayinler, mitler, azizler ve tapınaklarla desteklenmiştir (Llobera, 2007).

Bazı yorumlara göre millet ve etnisite ilişkisi açısından dinin taşıdığ önem, milletlerin tarihselliği ve evrenselliği meselesiyle ilintilidir (Yalç1ner, 2014). Bu yaklaşım milletlerin ilk ortaya çıkışı ile reformasyon arasındaki ilişkiye vurgu yapmaktadır. Millet bütününün ortak din paydasına göre tanımlandığı dönemlerin geride kalmasından sonra milliyetçilik adeta dinin tasavvur biçimleriyle ve misyonuyla aynı düzeye erişmiştir.

Din ve milliyetçilik ilişkisi bu yönüyle aydınlanma ve reform hareketlerinin etkisiyle papalığın gücünün sorgulanmaya başlanması ve Avrupa 
hanedanları arasındaki mezhep savaşlarına değin götürülebilecek bir derinliğe sahiptir. Fransız İhtilali'nin tetiklediği ve daha sonraki dönemde ulusların kendi kaderini tayin hakkı şeklinde kavramsallaştırılan modern milliyetçilik dönemi kadar reformasyon dönemi de din ve milliyetçiliğin ilişkisinin izlerinin sürülebileceği bir dönemdir. Zira milliyetçilik teorilerinde merkezi öneme sahip 'modern devlet'in miladı olarak, 30 yıl süren din/mezhep savaşlarının sonunda varılan 1648 Westphalia Barışı gösterilmektedir. Bu anlamda Katolik, Ortodoks ve Protestan mezheplerinin tarihte yaşamış oldukları savaşlar, milletleri oluşturan süreçlerin başlangıcı sayılabilir. Modern devletin oluşum sürecine paralel olarak geriye götürebileceğimiz din ve milliyetçilik ilişkisi bugün ise etnik milliyetçilikler bağlamında önem arz etmektedir.

Bu makale tarihsel bir perspektif sunmasa da milliyetçilik ve din ilişkisini, iki olgunun yollarının çatıştığı ve çakıştığ1 duraklar/örnekler özerinden anlamaya, açıklamaya çalışmaktadır. Bu çalışmada, kimliği oluşturan bu en güçlü iki bileşeninin birbiriyle ilişkisi, dinin milliyetçiliğe engel mi destek mi olduğu soruları etrafında dinin milliyetçilikler için merkeziliği tartışmasının genel hatları çizilmeye çalışılmıştır.

\section{Milliyetçilik ve Din Arasındaki İlişkiye Dair Tartışmalar}

İnsanlar ve toplumlar birçok farklı kimliği içinde barındırmaktadır. Ancak bu çoklu kimlikler zaman zaman çatışmaya yol açmaktadır. Hatta denilebilir ki Batı medeniyetinin inşası çoklu kimliklerin çatışmacı inşacılığı üzerine kurulmuştur. Amin Maalouf'un Ölümcül Kimlikler kitabında öne ç1kardığ1 tartışma ya da Anthony D. Smith'in Sofokles'in Kral Odipus oyununa atıfla yaptığı çıkarım, çoklu kimliklerin çatışmacı doğası ve kimliğin değişebilme özelliğiyle alakalıdır. Amin Maalouf, "Sahip olduğum çoklu kimliklerden birini öne çıkarmadan ve çatıştırmadan sahiplenmem mümkün müdür?" diye sorar (Maalouf, 2008). Aynı anda Lübnanlı, Arap, H1ristiyan, Fransız... olmak ve bu kimlik unsurlarının tamamını eşit şekilde sahiplenmek mümkün müdür? Smith ise çoklu kimlikleri, kimliğin değiştirilebilirliğine vurgu yaparak bahse konu eder: Ailevi, ülkesel, sınıfsal, etnik ve cinsel kimlik ve rollerden oluşan Oedipus'un hikayesi kimlik sorununu bütün keskinliği ile ortaya koyduğu gibi bu kimliklerin aynı zamanda nasıl olup da toplumsal sınıflamalara dayanak kılındığından söz 
eder (Smith, 1994). Kimliklerin toplumsal sinıflamalara dayanak olmas1 modern düşüncenin de temel varsayımıdır. 19. Yüzyıldan itibaren varlık kazanan modern seküler düşünce yapısı kimlikleri çatışmacı doğasıyla öne çıkardığı gibi kimlik inşasını da çatışmacı bir sürece sokmuştur. Dini ve etnik kimlik, tarihsel süreç içinde mekânsal ve zamansal farklılıklar gösterecek şekilde, bazen iç içe geçmiş ve birbirini beslemiş bazen birbirini ikame etmiş bazen dışlamış ama her durumda kurucu bir ilişki içinde olmuştur. Makalenin konusu bağlamında ele aldığımızda, din ve milliyetçilik ilişkisinde dikkate alınması gereken iki farklı yön söz konusudur. Dinlerin etnik uyanışın önünde bir engel olduğu görüşü ve dinlerin etnik uyanışı beslediği görüşü şeklinde ifade edebiliriz bunu.

Din ve milliyetçilik ilişkisini mekansallık ve zamansallık üzerinden değerlendiren araştırmacılar, belirli bir dini cemaatin, belirli bir toprak paçası üzerinde uzun süre yaşamış olmasının millet olma duygusuna ve bilincine yol açtı̆̆ını iddia etmektedir. Bu örtüşmenin tek tek başına belirleyici olduğu konusunda israrcı olamasak da milliyetçiliklerin inşasında zamanı ve mekanı kesen vatan kavramının oluşumu bu çerçevede ele alınabilir.

Din ve milliyetçilik ilişkisinde ilk elden söylenebilecek olan milliyetçiliğin dinlerin etkisinin azaldığ 1 bir dönemde ortaya çıtığı tezidir. Benedict Anderson da dinin bıraktığ nin milliyetçilik olduğu görüşündedir. Çünkü Anderson'a göre milliyetçilik tıpkı din gibi raslantısallığı kadere dönüştürebilecek bir kutsal büyü taşımaktadır ve millet, ezeli bir geçmişten gelmek ve bir ebede ilerlemek gibi kutsallaştırıcı söylemlere sahiptir (Anderson, 2015). Anderson'un "Dinin önemini yitirdiği ve milliyetçiliğin dinden boşalan yeri doldurduğu" tezine karşı çıkan da çok olmuştur. Kellas milliyetçilik ve din arasında her zaman bir ikame ilişkisi olmadığını, kimi durumlarda her ikisinin el ele verdiğini söylemektedir (Kellas, 1991). Aynı şekilde Greenfeld de milliyetçiliğin dinin yerine geçmek bir yana dini bağlılıkların en güçlü olduğu reform hareketi dönemlerinde ortaya çıtığını söylemektedir (Greenfeld, 2017). Smith de bu görüşü desteklemektedir. Çünkü ona göre dinler, milliyetçilik için son derece önemli olan mit ve sembollerin kaynağıdır (Smith, 1994). Smith burada etnilerin doğuş mitleri ile yaradılış hakkındaki dinsel inançlar arasındaki yakın ilişkiye dikkat çekmekte ve Yunanlıların ve Yahudilerin yaradılış mitlerini örnek vermektedir. Bu mitler 
hem milliyetçiliklerin kendilerine kutsallık atfetmelerine imkan sağlamakta hem de milliyetçiliklerin dini ikame işlevi görmesini sağlamaktadir.

Dinin bir yaşam biçimi olduğu topluluklara Ernest Gellner ve Anthony D. Smith tarım toplumu gibi dikey toplulukları örnek verir ve etnik topluluktan millete geçiş sürecinin buralarda sıkıntılı olduğunu çünkü dinin pek çok etnik grup tarafından paylaşıldığını söyler (Gellner, 2013). Smith ayrıca dinin, etnik kimlikleri donuklaştıran yönünden bahseder ve vatandaşlık kavramının öne çıktığı bir milletin oluşabilmesi için dinin geri plana itilmesi gerektiğini söyler (Smith , 1994).

\section{Milliyetçiliklerin Kaynağı Olarak Reformasyon}

19. Yüzyıl ve sonrası oluşan milliyetçilik cereyanlarında genel yaklaşım dinin millete bağlılı̆̆ı engellediği şeklindedir, Dini duyguların milli duygulara mani olduğu ve milletleşme sürecini engellediği tezi, Batı'da da Doğu'da da devletleri benzer süreçlere sokmuştur. Uluslaşma deneyimi, Türkiye, İran ve özellikle Batı hakimiyetine girmiş olan Arap ülkelerinde bağımsızlık mücadelesi sonrası kurulan rejimlerde alabildiğine baskıcı pratiklerle kendini göstermiştir. Fransız milliyetçiliğinin Fransız Devrimi'yle bitişen tarihi ve bunun Kiliseye başkaldırı şeklinde cereyan etmesi dinle sorun yaşayan milliyetçiliklerin temel referansıdır. Cumhuriyet Türkiye'sinde ulus devlet inşasının dine karşı baskıcı politikalarla yürütülmesi Fransız modelinin örnek alınmasıyla yakından ilişkilidir. Fransız İhtilali'nden ilham alan 19. Yüzyıl ulus devletlerinin sekülerizm ve pozitivizmi benimsemeleri ve devlet eliyle yürütülen modernleşme tecrübesi dini hayat üzerinde otoriter uygulamaları beraberinde getirmiştir. Osmanlı modernleşme deneyiminde olduğu gibi Kemalist modernleşme döneminde de devlet kurumları modernleştirme misyonunun taşıyıcıları olmuştur (Lewis, 1993). Otoriter modernleşmenin en bariz özelliği geçmişle bağları kopartmak üzere istisnai pratikler sergilemesi ve modernleşmeyi kitleselleştirecek yasalar ortaya koymasıdır.

Dini hayatın görünürlüğünü toplumda geriye itmekle sonuçlanan bu politikalar uluslaşma deneyiminde bir çıkış yolu olarak görülmüş ancak geçmişin radikal reddi üzerine kurulu otoriter modernizasyon örnekleri her zaman başarı kaydedememiştir. Hatta dinin, uluslaşma sürecine engel 
teşkil ettiği tezi ile toplumun dinden uzaklaştırılması politikaları zaman zaman tersi sonuçlar da üreterek dinin yeniden kitleselleşmesini ve siyasallaşarak geri dönmesini sağlamıştır. Türkiye örneğine bakıldığında çok erken evrede bu politikaların özellikle Kürt etnisitesinde milliyetçilik duygularını da destekler şekilde muhalif organizasyon ve eğilimlerin oluşmasına zemin hazırladığı görülecektir. Kürt siyasallaşmasının milli asabiyeye evirilmesinde, halifeliğin kaldırılması başta olmak üzere pek çok laikleştirici uygulamaya karşı Kürt dini aktörlerinin gösterdiği tepki belirleyici olmuştur.

İngiltere ve İrlanda arasındaki düşmanlığın da kökenlerinde Kilise'nin hakimiyetine karşı baş gösteren isyanlar yatmaktadır. Protestanlaşan İngiltere'nin Katolik İrlanda'yı hakimiyet altına almaya çalışması bunun ikinci adımı olmuştur. İngiltere Roma'dan ayrışıp Protestanlaşarak Anglikan kilisesini kurduktan sonra İngiltere ve İrlanda arasındaki mücadele Protestan-Katolik mücadelesine dönüşmüştür. Bugün hala devam eden Kuzey İrlanda sorunu, din ve milliyetçiliğin birbirini beslemesi sayesinde bu denli dayanıklı ve çözümsüz bir hal almıştır. Katolik dini kimlik, adanın güneyinin bağımsızlaşmasına yol açarken Kuzey İrlanda içindeki Protestan nüfus ise Katoliklere karşı Birleşik Krallık içinde kalmayı tercih etmiştir. Keza Hollanda'nın Katolik İsyapya'ya karşı verdiği bağımsızlık mücadelesinin de güç kaynağı Protestanlıktır (Baron, 2007). Din ve milliyetçilik ilişkisinde Reformasyon hareketinin etkisini Protestanlığın milliyetçilikle birlikte yükselmesinde gözlemlemek mümkündür.

\section{Kiliseden Güç Alan Milliyetçilikler}

Dini ve etnik kimlik arasındaki benzerliklerin bir kültürel sınıflama ölçütünden geldiğini, çoğu kez çakıştıklarını ve birbirlerini güçlendirdiklerini ve bu yolla tek tek ya da birlikte güçlü cemaatleri harekete geçirebildiklerini söyleyen Smith, "Milliyetçilik özünde laik bir ideoloji olsa da dini milliyetçilikte yadırgatıcı bir yan yoktur" der. Milliyetçiler bu anlamda sadece kitlelerin dini duygularına seslenme gereği duymakla kalmamışlardır. Sri Lanka, Ermenistan, Polonya ve İrlanda'da olduğu gibi dini toplulukları etnik topluluk dairesinde tanımlamak yoluna da gidilmiştir (Smith, 1994). 
Din ve milliyetçilik arasındaki benzer ilişki biçimine dair örnekleri çoğaltmak kolaydır. Örneğin Balkan Savaşları'nın temelini oluşturan isyanların İslam dinine karşı kiliseden güç aldıkları gibi Osmanlı millet sisteminin dini temelli oluşundan beslendikleri de söylenebilir. Burada da din ve milli kimliğin çatıştığı ve çakıştığı bir süreç yaşanmıştır. Öyle ki burada hem Osmanlı'ya hem de örneğin Bulgarlığın asimile olduğu Rumlara karşı bağımsızlık mücadelesinde kilise merkezi yerdedir. Çünkü zengin ve kültürlü Bulgarlar, kendilerini Rum görüyor ve bununla gurur duyuyordu. Ayrıca Fener Patrikhanesi, Bulgarları Rumlaştırmaya çalışıyordu (Şimşir, 2009). Bu anlamda Bulgarların kendi ulus kimliğine dönüşüne öncülük eden ismin bir papaz olması dikkate değerdir. Papaz Paisii Hilendarski tarafından 1762 yılında yazılan Slav Bulgar Tarihi isimli kitabın Bulgar uyanışına öncülük ettiği kabul edilir. Paisii Hilendarski, Osmanlı egemenliğine karşı olduğu kadar, Rum kilisesinin Bulgarlar üzerinde etkinlik kazanma politikalarına da karşıydı ve Bulgarları kendi dillerinin kutsallığını korumaya ve kendi kiliselerinin bağımsızlığı için de mücadeleye çağırmaktaydı. Slav Bulgar Tarihi adlı kitabının önsözünde şöyle diyordu:

Halkını ve Bulgar yurdunu seven, onları yüreğinde taşıyan ve Bulgar halkının, babalarınızın, atalarınızın, çarlarınızın, yurtseverliğinizin ve azizlerinizin hakkında ne bildiğini, geçmişte nasıl yaşamış olduklarını ve başlarından neler geçtiğini öğrenmek ve bilmek isteyen, okuyucu, dinleyici, Bulgar halkı; dikkatle dinleyin. Sizlerin de nasıl ki tüm diğer kavimler ve halklar kökenlerini biliyor, dillerini tanıor ve bir tarihe sahip bulunuyorsa ve okuma yazma bilen herkes halkını ve dilini tanıyor ve konuşuyor, bundan gurur duyuyorsa, atalarınızın yapıp ettikleri konusunda neyin bilindiğini öğrenmeniz gereklidir (Tadarov, 1979).

Sadece Bulgarların değil, yüzyıllar boyunca Osmanlı hakimiyetinde yaşamış olan Yunan, Ermeni, Süryani ve Sırp milletlerinin Osmanlı millet sisteminin de katkısıyla kendi milli kimliklerini müstakil kiliseleri üzerinden kurdukları ve kiliselerini de milletlerinin çağlar boyu sürekliliğini kanıtlayan bir kurum olarak sundukları görülecektir (Aktürk, 2006). Osmanlı millet sisteminin söz konusu etnik kimlikleri farklı milletler olarak kabul etmesi de bu dini cemaatleri Ortodoks mezhebinin kapsayıcılığından çıkardı. Şener Aktürk'ün ifadesiyle "Milliyetçilik ele alınan örneğe bağlı olarak kendinden önceki dini kurumlar ve kavramlarla görece süreklilik arz edebildiği gibi (Süryani, Ermeni vd.) radikal bir kopuşu da 
ifade edebilmektedir (pek çok Katolik, Ortodoks ve İslam toplumunda)" (Aktürk, 2006).

Balkanlar'daki milliyetçilik dalgalarında din hep çok önemli bir etken olarak ortaya çıkmıştır. İkinci Dünya Savaşı sonrası kurulan düzenin sonunu getiren Balkanlar'daki parçalanma süreci Hristiyanlığın kendi içindeki mezhebi farklıklardan beslenmiştir. 1990'lar boyunca bir etnik çatışma olarak görülen krizin asıl besin kaynağını din ve mezhep farklılıkları oluşturmuştur.

Yugoslavya'nın parçalanmasında ve soykırıma dönüşen Bosna Savaşı'nda din en önemli etken olmuştur. Sırp ve Hırvat milliyetçilikleri öteden beri güçlü dinî milliyetçilikler olarak bilinmektedir. Örneğin Hırvat Katolik kilisesi, tarih boyunca Hırvat ulusal kimliğinin kurucu unsuru ve koruyucusu olmuştur (Sancaktar, 2019). Hepsi Slav olan Boşnak, Makedon, Hırvat, Sırp ve Slovenleri, Slav kimliğinde değil de din ve mezhep milliyetçiliği üzerinden kategorize edilmektedirler. Boşnaklar Müslüman iken, Sirp ve Makedonlar Ortodoks Hıristiyan, Hirvatlar ve Slovenler ise Katolik Hıristiyanlar'dır. Birbirleri ile olan savaşlarında etkin olan ırk değil başta mezhep olmak üzere dindir.

Görüldüğü üzere din ve milliyetçiliğin karşılıklı etkileşimi konusunda Balkan coğrafyası adeta bir labratuvar niteliğindedir. Balkanlar'da dinin milliyete dönüşmesine en belirgin örneklerden biri de Müslüman Boşnaklardır. Yugoslavya'nın bir parçası olarak Bosna'da yaşayan Müslümanların kimliklerindeki milliyet bölümüne Müslüman yazma hakkı için mücadele etmeleri ve kazanmaları Gellner'e göre dinin milli kimlik oluşturmasına dair dikkat çekici bir örmektir. Boşnaklar da son tahlilde Slav kökenli, Sırpça-Hırvatça konuşan Müslümanlardır. Gellner'e göre milliyet boşluğuna Müslüman yazmak için verilen mücadele kendilerini aynı dili konuştukları Müslüman olmayan kesimden ayrıştırmanın bir yoludur. Aksi takdirde onlar da Katolik ya da Ortodoks görülebileceklerdir. Kendilerine Yugoslav demenin ise onlar için bir anlamı yoktur (Gellner, 2013).

Gellner gibi pek çok Batılı düşünür din ve ulusçuluk arasındaki ilişkiyi Batı modernleşmesi ve Protestanlık arasındaki ilişki üzerinden okumuştur. Gellner, “Reformasyon'un okur yazarlık ve kitaba bağlılık konusunda yaptığı baskının, tekelci rahipliğe saldırısının, bireycilik ve hareketli kentli nüfus ile olan bağlarının reformasyonu ulusçu çağa yol açan toplumsal özellik ve davranışların bir habercisi yaptığını" belirtir. Buradan hareketle 
Gellner, İslâm dünyasındaki son yüzyılda ortaya çıan reformculuğu (Gellner buna da "İslâm Protestanlığı" der) modern Arap ulusçuluğunun tarihiyle örtüştürür (Gellner, 2013). Arap milliyetçiliğinde Selefî tonla ortaya çıkan yorum, kendini Osmanlı'ya karşı farklılaştırma eğiliminin bir neticesidir. Aynı zamanda İslâm'ı, Peygamberinin Arap olması ve Arapça konuşması dolayısıyla Arap kimliğinin oluşmasında merkezî bir yere koymak da Araplık ve Müslümanlık arasındaki ayrışmaz kimliğin bir göstergesidir. Bu konuda en fazla çalışanlardan biri olan Alan R. Taylor, Arap milliyetçiliğinin gelişmesinde İslâm'ın Araplar için biricikleştirilmesi sürecine dikkat çekmektedir. Bir Arap Hıristiyanı olmasına rağmen Michel Eflak'ın İslâm'ı bir Arap hareketi olarak değerlendirmesi ve Hz. Muhammed'in Arap milletinin yaratılmasındaki önemi üzerinde durması ve bu düşüncelerini politik bir platforma taşıyarak 1943'te Baas Partisi'ni kurmasını örnek verir (Taylor, 1982). Taylor da tıpkı Gellner gibi Arap milliyetçiliğinin doğuşundaki reformcu etkiye dikkat çeker ve Arap milliyetçilik hareketinin düşünsel temellerinin Selefî akım ile atıldığını söyler (Taylor, 1982).

Sömürgeciliğe karşı gelişen pek çok bağımsızlık hareketinin sembol isimlerinin dini önderlerden oluşması da dinin milli kimlikleri beslediğine dair önemli örnekliklerdir. Libya'da Senusi Hareketi liderlerinden Ömer Muhtar, Cezayir'de bağmsızlık sürecinin sembol isimlerinden olan Kadiri tarikat şeyhi Abdülkadir Cezayiri ve Nakşibendi tarikat şeyhi olan Kafkaslar'daki ünlü Çeçen lider Şeyh Şamil gibi isimler toplumlarında dini ve milli liderlik görevini aynı anda üstlenmiş şahsiyetlerdir. Benzer şekilde Irak Kürtlerinin bağımsızlık mücadelesinin lideri olan Molla Mustafa Barzani de aynı zamanda bir tarikat şeyhidir.

Hem milliyetçilik ve din ilişkisine farklı bir boyut getirmiş olması hem de milliyetçilik ideolojisinin ne olduğuna dair dikkat çekici bir örnek olması hasebiyle Hıristiyan Gagavuz Türklerinin Türkiye'ye göç etmek istemelerine rağmen kabul edilmemeleri, Türk-Yunan nüfus mübadelesinde Hiristiyan Karaman Türklerinin ise Yunanistan'a gönderilmesi örneğini zikretmek yerinde olacaktır. Gagavuz Türkleri'nin Balkan Savaşlarında Müslüman Türklere karşı gelişen isyan hareketine dahil olmaları da bu anlamda önemli bir veridir. Bu durum, Osmanlı millet sisteminin din temelli olmasına örnek oluşturmasının yanı sıra milliyetçilik ve din arasında birbirini besleyen bir ilişki olduğu tespitine de imkân vermektedir. 
Şener Aktürk bu örneği, yani Gagavuz Türklerinin sırf Hıristiyan oldukları için Türk olmayan gayrimüslimlerle bir tutulup Türk ulusundan dışlanmalarını, Türk ulusçuluğunun toprağa bağlı tanımlanmadığı iddiasının doğruluğuna kanıt saymaktadır. Aktürk Türk ulusallığının anti-etnik ancak tek dinli tanımlanabileceğini söyler (Aktürk, 2015). Buna mukabil tek dinli olan bu Türk ulusallığı aynı zamanda laik, modern ve Batılıdır.

Türk ulusçuluğu örneğinde de görüldüğü üzere Hobsbawm, dinin modern milliyetçilikler için paradoksal biçimde bir çimento işlevi gördügüüü söyler (Hobsbawm, 1995). Çünkü modern ulusçuluklar dine, üyelerinin bağlılığı üzerinde tekel kurmasına mani olacak bir güç olarak bakar ama aynı zamanda dinin birleştirici misyonundan da istifade etmek ister.

Kendi başına çok derin ve çok yönlü bir konu olmakla birlikte İran'da Şiiliğin Safeviliği örten bir yüzünün olması, Şiiliğin İran'daki farklı etnik kimlikleri bir üst kimlik çerçevesinde kapsayan ve tümünü Pers ya da ikinci büyük etnik kimlik olan Azeriliğe (Türklüğe) değil hepsini birden Şiiliğe asimile etmesi etniklik ve din çakışmasından farklı bir din-etnik kimlik ilişkisine örneklik teşkil etmektedir. Din ve etnik kimlik, çakıştıkları zaman birbirini güçlendirirler. Bunun tersini söylemek de mümkündür. Ortak dinler, etnik farklılıkların aşılması ya da önemsizleşmesi gibi bir sonuç da doğurabilir. İnsanlık tarihinin büyük bölümünde dinî ve etnik çifte kimlik dairesi, özdeş olmasa da birbirine yakın durmuştur. Bu ilişkinin her zaman besleyici değil farklı etnik kimliklerin aynı dinî kimliği paylaşması durumunda etnik kimliği zayıflatıcı yahut ikinci plana itici bir etkisinden bahsedilebilir.

$\mathrm{Bu}$ örneklerden de görüleceği üzere büyük dinlerin evrensel esaslarının, ulus milliyetçiliklerini ya da etnik milliyetçilikleri tasvip etmemesine rağmen, uluslaşma sürecinde ne denli etkili oldukları ortadadır. Dinî farklılaşma, kendini baskın kimlikten farklılaştırma imkânı sağlarken din ve mezhep birliği, etnik kimliği ikinci plana iten bir işlev de görebilmektedir. Milliyetçiliklerin dini kökeni olduğu gibi dinin milli uyanışı engellediği örnekler de söz konusudur. 


\section{Dinin Etnik Kimliğe Dönüşmesi}

Anthony Smith, dünya dinlerinin etnik grupları ve etnik sınırları aşmaya çalışırken belli etnik grupların kendilerini korumak adına en dindar cemaatlere dönüşebildiğine dikkat çeker. Etnisite ile dinin çakışmasına tekabül eden bu duruma örnek olarak da Smith Ermenileri, Yahudileri, Habeşlileri ve Kıptileri verir. Başlangıçta dini bir cemaat olarak yola çıkan bu topluluklar zamanla kendine özgü etnik bir yapıya dönüşmüştür. Örneğin Hıristiyanlığın ilk yüzyıllarında, kurumsallaşma sürecinde konsillerde alınan bir takım kararları kabul etmeyerek müstakil kiliseler edinen Kıptiler ve Ermenilerin durumu buna örnektir. Smith buna ayrıca Misır'da Şiilik çerçevesinde bir mezhep şeklinde ortaya çıkan ancak burada eziyete uğrayan Dürzileri örnek gösterir. Dürziler gördükleri eziyet dolayısıyla Mısır'ı terk eder ve Lübnan Dağı'na yerleşirler. Dinin etnileşmesine dair bu çarpıcı örneği Smith şu şekilde anlatır:

Dürziler kale gibi korunaklı Lübnan Dağı'na gittiler ve burada 11. yüzyılın ilk on yıllarında Araplar kadar Kürt ve İranlıları da aralarına aldılar. Ama son büyük hocaları Baha'al Din'in ölümü üzerine mühdediliği bıraktılar. Cemaate üyelik dışarıdaki hasımların korkusundan sabit bir hal aldı. Cemaate giriş çıkışlara izin verilmiyordu. Çok geçmeden Dürzîler soyu sopu olan şeceresi belli, toprak sahibi bir cemaat haline geldi. O halde bugün Dürzî olmak 'etno-dinsel' bir topluluğa mensup olmak demektir (Smith, 1994).

Ermenilerin çok erken bir dönemde müstakil kiliseleriyle Batı Hıristiyanlığından ayrışmak suretiyle etnik-dini bir topluluğa dönüşmelerinin yanı sıra Osmanlı toplumu içinde Ermenilerin Müslümanlaşmak suretiyle Ermenilerin kimliklerini yitirmesi ve Türkleşmesi olgusunu da burada zikredebiliriz. Ayrıca Osmanlı'nın Müslüman temsilinden hareketle Batı medeniyetinin Müslüman kimliğini Türk kavramıla ifade etmesi ve $\mathrm{H}_{1}-$ ristiyanlığı seferber ederken 'barbar Türkler' tanımlamasını kullanması da bu çerçevede değerlendirilebilir. Bu anlamda Türk kelimesi Batılı metinlerde sıklıkla Müslüman yerine kullanılmıştır (Akdemir, 2007). Aynı şekilde Ermenilerin Müslüman olmak suretiyle Türkleşmeleri, Türk ve Müslüman kimliğinin çakışmasıyla ilgilidir. Smith'in ifade ettiği husus yani Ermeniliğin etno-dinsel bir kimlik olması Hıristiyan kimliğinden ç1kışla birlikte Ermenilik kimliğinden çıkışı da beraberinde getirmiştir. 
Yahudiliğin İsrailoğulları'na münhasır addedilmesi de dinin etnileşmesine bir başka örnektir. Doğuşu itibariyle İsrailoğulları ile özdeşleşen Yahudilik, bu bakımdan millileşmesi en kolay dindir (Öğün, 2000). Bulundukları toplumlarla kaynaşmalarına mani olan bu özellikleri, kolay dışlanmalarına ve milliyetçilik dalgasından da bulundukları topluma göre zarar görmelerine sebep olmuştur. Çok farklı coğrafyalarda çok farklı kültürel iklimlerde yaşamış olan Yahudilerden bir millet oluşturma çabası "Yahudi kimdir?" sorusuna bir cevap arayışıdır. Bu İsrail devletinin kurulmasıyla ve özellikle de İsrail'e dönüş yasası bağlamında çokça tartışılmiştır.

Dinin kendini korumak adına içe kapalı cemaatlere dönüştüğü ve giderek etnikleştiği Dürziler, Kıptiler, Ezidiler gibi örnekler aynı zamanda belli etnik grupların kendilerini korumak için dindarlaştığ 1 formlara da örnek gösterilebilirler. Ermeniler, Yahudiler ve Monofiziz (İsa' da Tanrı ile insanın birliğini gören bir Hıristiyan tarikat) Habeşliler, Mısır'ın Kıptîleri, bu (etnik-dinî) çakışmanın klasik örneklerinden sayılmaktadır (Smith, 1994).

\section{Osmanlı'da ‘Dini Millet’ Tasnifi ve Milliyetçiliğe Etkileri}

Osmanlı'daki dini temelli millet sistemi milliyetçiliklerin dini temelleri ve din milliyetçilik ilişkisi bağlamında hususi bir örnektir (Lewis, 1993). Millet kavramı Osmanlı'da özelleşmiş bir anlam kazanarak farklı dinî geleneklere mensubiyeti ifade etmek için kullanılmıştır. Kelimenin Osmanlı döneminde taşıdığ 1 dini anlamı yitirmesi ve 'nation'un Türkçeye 'ulus' şeklinde geçmesi, kelimenin siyasi ve sosyolojik bir bağlama eklemlenmesi sürecinin sonundadır. Benzer bir durum Avrupa için de geçerlidir. Nation kelimesi, din temelli değilse de Batı Avrupa'da da uzun müddet belli bir bölgesel veya yerel topluluğu ifade etmek için kullanılmıştır (Keskin, 2016). Yani modern ya da etnisite temelli millet olgusundan farklıdır.

Osmanlı egemenliğinin uzun dönemi boyunca millet sisteminde gayrimüslim azınlığın tabiiyetini belirleyen Kilise, 20. Yüzyılda baş gösteren milliyetçiliklere de ebelik yapmıştır. Osmanlı millet sistemi de dini esas aldığ için, Ermeni, Rum ve Yahudileri farklı millet sayıp Müslüman halkı farklı etnik kimliklerine rağmen tek millet olarak değerlendirmiştir. Yine 
bu sebeple, yeni devletin kurucu metni sayılan Lozan Anlaşması'nda Kürtler azınlık statüsünde değerlendirilmemiştir.

Osmanlı'nın millet tanımından farklı olarak Cumhuriyet Türkiye'si millet kavramını nationun karşılığ "anti-etnik" bir uluslaşmayı model almış ancak Türk kimliğini tüm etnik kimlikleri eriten bir üst kimlik potası olarak kurmayı en azından Kürtler özelinde başaramamıştır (Aktürk, 2015). Bunun sebebi olarak ta Türklüğün ırk, soy, sop şekline bürünmesi gösterilmiştir. Bir başka sebep de sebep, uluslaşmanın aynı zamanda dini geriletme sürecini içermesi ve millet kavramının dini 1stılahının giderek geri plana itilmesidir. Dini içeriğinden arındırılan Türklük, Kürtlerin kendilerini ait hissedebildikleri bir kimlik olmaktan çıkmıştır. Oysa millet, ümmet anlamını da içeren bir kavramdır ve ümmet Müslümanları birbirine bağlayan çok keskin bir bilinci ifade etmektedir (Mardin, 1993). Dini çekip aldığınızda yerine bir şey ikame etmeniz gerekir. Milliyetçiliğin yarattığ 1 ortak duygunun böyle bir işlev gördüğü söylenebilir.

Osmanlı'nın son döneminde imparatorluğu bir arada tutabilmek için geliştirilen "üç tarz" siyasetten birinin İslâmcılık olması milletin inşasında dine yüklenen misyonun bir başka göstergesidir. Kürtlerin anâsır-1 İslâm olarak Türk milletinin ve yeni kurulan devletin bir parçası sayılmasında İslâm ortak paydası, Sünni Müslümanlık en önemli etkendir. 1876-1909 yılları arasında pan-İslâmist politikalarla imparatorluğu bir arada tutmaya çalışan II. Abdülhamid' in tüm Sünni tebaayı kendisine bağlı kılmak için yürürlüğe koyduğu ve Ermenilere karşı doğuda Kürtleri görevli kıldığı Hamidiye Alayları'nın bu politikada çok etkili olduğu ifade edilmektedir (Kodaman, 1987). Çünkü hilafetin sancağı altında olmayı önceleyen Kürtlerin Sultan Abdülhamit'e olan bağlılıkları milliyetçi duygularına üstün gelmiştir (Bruinessen, 2008). Osmanlı'daki farklı etnik unsurları kaynaştırabilen İslâmlık ortak paydasının giderek marjinalleştirilmesi ise Kürt siyasallaşmasının dinamiklerinden birine dönüşmüştür (Davison, 2012). Bu aynı zamanda, sekülerizmin devlet ideolojisi hâline getirilmeye başlandığı sürece tekabül etmektedir. Taşıyıcı ideoloji İslâm olmaktan çıkıp Türk milliyetçiliğine dönüştükçe Kürtlerin devletle olan bağ1 da o oranda zarar görmeye başlamıştır. Martin Van Bruinessen bu durumu şu şekilde ifade eder: “Devleti taşıyıcı ideoloji olarak İslâm'ın yerine Türk milliyetçiliğini yerleştirme çabaları dindar taşralı Kürtlerin yönetime olan 
soğukluklarını perçinlemiş̧ir" (Bruinessen, 2008). Dolayısıyla Kürtler için uluslaşma bilincinin oluşumu ile Türk ulus devletinin kurumsallaşması sürecinin paralellik arz ettiğini söylemek mümkündür.

\section{Kürt Milliyetçiliğinin Dinle Meselesi}

İmparatorlukların dağıldığı, ulus devletlerin ve ulusçuluğun yükseldiği döneme eşlik eden modernleşmenin yeni bir safhası tabir edilebilecek post-modern dönemin olgunlaştırdığı kültürel hegemonya çağında din ve milliyetçilik ilişkisi bu sefer de başka bir bağlamda önem kazanmıştır. Post-modern dönemin karakteristiğini yansıtan ulus altı kimliklerin tanınma talepleri, Batı dünyasında daha ziyade birey hakları çerçevesinde ele alınırken etnik ve mezhebi kimliklerin inkar ve asimilasyon politikaları dolayısıyla siyasallaştı̆̆ı Türkiye gibi ülkelerde etnik kimliğin egemenlik paylaşımı talebi şeklinde kendini göstermiştir. Bağımsız bir Kürt devleti talebiyle ortaya çıkan ve 1980'den sonra evvela Kürt köylerinde gerçekleştirdiği silahlı terör eylemleriyle adını duyuran PKK, kendi yandaşını yarattığı gibi PKK ile çatışan başka Kürt siyasal kimliklerinin de doğmasına zemin hazırlamıştır. Böylece, milliyetçilik ve din ilişkisinin yeniden daha alt kategoride sorunsallaştığı bir durum ortaya çımıştır.

Örneğin Marksist Leninist bir örgüt olan PKK, dindar Kürtler arasında taban bulabilmek adına katı din karşıtı söylemlerinden kısmen vazgeçmiştir. Bu çerçevede PKK ve siyasi uzantısı sayılan partiler, kendi kontrollerinde bulunacak bazı dini kurumlar (Kürt İmamlar Derneği, İslam Kongresi) ihdas etmiş yahut dini kimliğiyle bilinen kişileri (Altan Tan, Nimetullah Erdoğmuş, Kadri Yıldırım gibi) milletvekili listelerine almıştır. Bu taktik değişiklik, din üzerinden Kürtler arasında popülerlik sağlamak şeklinde değerlendirilebileceği gibi dindar Kürtlere Kürt milliyetçiliği üzerinden yaklaşmak da olarak da görülebilir.

Aynı dine mensup olmanın ortak millet tasavvuruna katkı yaptığı örneklerin tersine aynı dili konuşan unsurların dini farklılık dolayısıyla farklı etnik kimlik olarak görülmesine bir örnek de etnik anlamda Kürt olan Ezidilerdir. Tıpkı Gagavuz Türklerinin Müslüman olmadıkları için Türk milleti içinde görülmemeleri gibi Kırmançi lehçesini konuşmalarına rağmen Ezidiler de Müslüman Kürtler tarafından Kürt kabul edilmemiştir (Bruinessen, 2008). Kürt etnisitesi, Türk milleti üst kimliği ve Türk devleti 
altında ne tam manasıyla asimile olmuş ne de egemenlik talebindeki siyasal harekete rağmen toplumsal bir kopuş yaşamıştır. Kuşkusuz bunda ana etmen İslâm ortak paydası ve kültürel geçişkenliklerdir. Kürt kimliği hem dini hem de etnik bir kimliğe işaret etmektedir. Alevi ve Sünni Müslüman Kürtler arasındaki farklılaşma Kürt kimliğinin bu iki yönünü tahlil etmek adına önemlidir (Çiçek, 2015). Zazaki konuşan Alevi Kürtlerin Kurmançi konuşan Sünni Kürtlerden daha seküler oldukları ve ayrılıcçı Kürt hareketinde Alevi Kürtlerin ağır bastığı tespiti dini birlikteliğin bağlayıcı etkisine örnek verilebilir.

Dinin Kürt halkının siyasi bilincini canlı tutan bir işlev görmüş olmasına rağmen başta Şeyh Said İsyanı olmak üzere erken dönem Kürt isyanlarının Kürtlük bilincinden ziyade dini saikle yapıldı̆̆ı tezi ağırlık kazanmıştır. Ancak bu tez aynı zamanda dini etmenlerin siyasal bilince etkisini de kanıtlar niteliktedir. İsyanın dini nedenlerle gerçekleşmiş olması Kürt etnik kimliğine etki etmediği anlamına gelmez. Bilakis bugün dindar Kürt siyasi aktörlerin Kürtlük adına ilk referansları Şeyh Said isyanıdır. Öyle ki bu isyan, Kürtlerin İslam dinini muhafaza görevinin bir yansıması olarak görülmektedir. Bu dönemde aşiret ve tarikatlara göre Kürtlüğü savunmak Kürt milliyetçiliğini değil İslâm'ı savunmak anlamına geliyordu (Bruinessen, 2008). Kürt aşiret reislerinin, şeyhlerin ve eşrafın Müslüman KürtTürk kardeşliği için Paris Konferansı'na bir Kürt devleti projesini reddettiklerini açıklamak için yüzlerce telgraf göndermeleri ve projenin savunucusu Şerif Paşa'yı sert dille eleştirmeleri Kürtlüğü müdafaanın dini müdafaa anlamına geldiğine bir örnektir (Bozarslan, 2008). Fakat yine de Cumhuriyetin ilk yıllarında gerçekleşen bu isyan din ve milliyetçi duyguların tahlili anlamında önemlidir. İsyana Alevi Kürt aşiretler katılmamış, hatta karşı çıkmıştır. Koşgiri ayaklanmasına ise tam tersine Sünni Kürt aşiretler katılmamıştır (Bruinessen, 2010). Milliyetçi karakter taşısın ya da taşımasın Şeyh Said isyanı şeyh ve ağaların devlet ile karşılıklı etkileşimine örnek teşkil etmiş ve Kürt milliyetçiliğini beslemiştir (Bruinessen, 2008).

\section{Sonuç}

Bu makale, din ve milliyetçilik arasındaki ilişki biçimlerini tarihsel ve güncel örnekler üzerinden tartışmayı amaçlamıştır. Dinlerin milliyetçilikleri 
beslediği, milliyetçiliğin dini ikame ettiği, dinin etnileştiği ya da etnik kimliğin kendini korumak adına dindarlaştığı, dinin uluslaşmaya mani olduğu ya da tam tersi dinin etnik kimliğin kendini farklılaştırmasına yardımcı olduğu durumlar ele alınmış bu hususiyetleri taşıyan örnekler üzerinden açıklanmaya çalışılmıştır.

Milletlerin ve milliyetçiliğin doğuşu dinlerin bazen yardımı bazen de engellemesi ile karşılaşmıştır. Bu makale kapsamında değindiğimiz ya da değinemediğimiz örnekleri tarihsel süreç içinde ele aldığımızda şu çıkarımı yapmak mümkündür. Din ve milliyetçilik arasında ilerlemeci bakış açısının ürettiği doğrusal bir ilişki olacağını varsayan modern aydınlanmacı tezin aksine dinler milliyetçilikler içinde çok güçlü damarlar olarak varolmaya devam edebilmiştir. Dinler milliyetçiliklerin parçalayıcı etkisini azaltabilmiş, ancak bu süreçleri tümden tersine çevirebilecek sonuçlar üretmeleri mümkün olmamıştır. Farklı dini ve mezhebi kimlikler etnik farklılıklarla örtüştükleri zaman uluslaşma süreci daha hızlı ve kolay olabilmektedir. Ancak etnik kimlik bir kere siyasal hüviyet kazandıysa ortak dini kimlik bunu tümden ortadan kaldıracak imkanı sunmamaktadır. Çünkü modern dönemde etnik kimlik devlet rejimleri için bir belirleyici olarak kabul görürken dine böyle bir alan açılmamıştır. İsrail gibi din temelli siyasal rejimler de zaten din ve etnisitenin örtüştüğü dinin etnileştiği hususi örneklerdir.

Ezcümle, milliyetçiliğin tarihini Fransız İhtilali'ne dayandırsak ya da papalık kurumu ve Roma'nın otoritesinin sarsılmaya başlamasıyla yol bulan reformasyona götürsek de milliyetçiliği tek başına ele almak imkansızdır. Milliyetçiğin dinle ilişkisi bu anlamda kurucu bir ilişkidir. Dinler, milliyetçilikler için olmazsa olmazdır. Dinin, arkaik, gerici, millet kurmaya engel görüldüğü durumlarda da bu böyledir, milliyetçiliklerin dinden beslendiği durumlarda da. 


\section{EXTENDED ABSTRACT \\ The Relationship between Religion and Nationalism: Is it Facilitating or Complicating? \\ * \\ Halime Kökce \\ Marmara University}

The relation between nationalism and religion is plausibly considered the most complex, mutually exclusionist and simultaneously the most complementary form of relations dominating the social sphere. Prevalent standpoint sees that religion began to lose power with the emergence of nationalism in its contemporary definition. The experience of Western Europe confirms this thesis. On the other hand, there are many examples supporting the idea that religion and nationalism feed off each other, as well as the idea that nationalism repudiates the religion or substitutes the space left out by it.

Though the thesis defending the withdrawal of religion from life as long as rationality prevails was once the self-confident theses of enlightenment and positivism, it is now known that religion has not disappeared in any way, on the contrary, it has the power to determine social and political life with all its visibility. Nationalism, which prevailed with the French Revolution is nearly the sanctification of the secular state. The reformation period, as well as the modern nationalism one, which was triggered by the French Revolution and later conceptualized as the right of nations to self-determination, is the period during which the traces of the relation between religion and nationalism can be traced. The relation between these concepts, which we can take back alongside the modern state formation process, is as important nowadays, in the context of ethnic nationalism.

Notwithstanding the eclipse of the historical perspective in this article, it tries to understand and explain the relation between nationalism and religion through the examples and contextualization where the paths of the two phenomena collide and overlap.

In this study, the objective is to draw the general lines of the debate on the religion centrality for nationalism while emphasizing questions about 
the relationship between these two most powerful components of identity and whether religion is an obstacle or a support to nationalism.

The emergence of modern secular mentality in the 19th century, has brought identities to the fore with their confrontational nature as well as putting identity construction into a conflicting process. Religious and ethnic identity, showing spatial and temporal differences in the historical process, sometimes intertwined and fed each other, sometimes substituted each other, sometimes excluded each other, but in every case they were in a constitutive relationship. When we consider it in within the framework of the article, there are two different aspects that should be considered in the relation between religion and nationalism. The first one being the perspective that religions are an obstacle to the ethnic awakening and the second one, the view that religions feed the ethnic awakening.

Numerous are the examples that can be given to illustrate the type of relation between religion and nationalism. For instance, it can be said that the rebellions, which formed the basis of the Balkan Wars, were powered by the church against the religion of Islam, as well as being fed by the religious-based nature of the Ottoman Millet system.

Religion has always emerged as a very important factor during the milestones of nationalism in the Balkans. The disintegration process in the Balkans that conducted the end of the order established after the Second World War, was fed by the sectarian differences within Christianity itself. Despite being observed as an ethnic conflict, the main source of the 90s crisis, was religious and sectarian differences.

Religion was the main element in the dissolution of Yugoslavia also in the Bosnian War, which turned into a genocide. Serbian and Croatian nationalisms have long been known as strong religious nationalisms. To illustrate, the Croatian Catholic church has been the founding element and protector of Croatian national identity throughout history (Sancaktar, 2019). Bosnians, Macedonians, Croats, Serbs and Slovenes, all of whom are Slavs, are not categorized by their Slav identity, but by religion and sectarian nationalism.

The symbolic names of many independence movements developed against colonialism, consisting of religious leaders, are also important examples defending the thesis emphasizing religion as a supply to national identities. Names such as Ömer Muhtar, one of the leaders of the Senusi 
Movement in Libya, the Qadiri sect Sheikh Abdülkadir, one of the symbolic names of the independence process in Algeria, and the famous Chechen leader Sheikh Shamil in the Caucasus, who is the Sheikh of the Naqshbandi sect, all of them are personalities who have undertaken the task of religious and national leadership in their societies. Similarly, Mullah Mustafa Barzani, the leader of the Iraqi Kurds' struggle for independence, is as well, a sect sheikh.

Researchers assessing the relation between religion and nationalism in terms of spatiality and temporality claim that giving that a certain religious community has lived on a certain piece of land for a long time leads to the feeling and consciousness of being a nation. Although we cannot assert that this overlap is decisive on its own, the formation of the homeland as a concept, which cuts time and space in the construction of nationalisms, can be handled within this framework.

The emergence of nations and nationalism has been met with the help of religions and sometimes their hindrance. It is possible to make the following inference when we consider the examples we have mentioned or not mentioned within the scope of this article, in the historical process. Contrary to the modern Enlightenment thesis, which assumes that there will be a sequential relation between religion and nationalism produced by the progressive perspective, religions have continued to exist as very strong veins in nationalism. Religions have been able to reduce the disintegrating effect of nationalisms. However, producing results that can entirely reverse these processes was not feasible. When different religious and sectarian identities coincide with ethnic differences, the process of nationalization can be faster and easier. However, once ethnic identity has gained a political identity, common religious identity does not offer the opportunity to completely eliminate it. Because in the modern era, while ethnic identity was accepted as a determinant for state regimes, such an area was not opened to religion. Religion-based political regimes, such as Israel, are also special examples of ethnicity where religion and ethnicity overlap.

In conclusion, it is impossible to tackle nationalism separately, even if we attribute the history of nationalism on the French Revolution or conduct the analysis to the reformation led by the weakening of the papal 
institution and the authority of Rome. In this sense, the relation of nationalism with religion is a constitutive relation. Religions are imperative for nationalism. It is a case by case, there are times where religion is seen as archaic, reactionary and an impediment for the founding of a nation, and others, where nationalism is fueled by religion.

\section{Kaynakça / References}

Akdemir, E. (2007). Avrupa aynasında Türk kimliği. Ankara Avrupa Çalışmalarl Dergisi, 7(1),131-148.

Aktürk, Ş. (2006). Etnik kategori ve Milliyetçilik: Tek etnini, çok etnili ve gayri etnili rejimler. Doğu Batı Dergisi, 38, 23-53.

Aktürk, Ş. (2015). Almanya, Rusya ve Türkiye'de etnisite rejimleri ve milliyet. İstanbul: İstanbul Bilgi Üniversitesi Yayınları.

Anderson, B. (2015). Hayali cemaatler Milliyetçiliğin kökenleri ve yayılması (Çev. İ. Savaşır). İstanbul: Metis Yayınları.

Baron, S. W. (2007), Modern Milliyetçilik ve din.(Çev. Mehmet Özay). Istanbul: Açlım Kitap Yayınları.

Bozarslan, H. (2008). Türkiye'nin modern tarihi. İstanbul: Avesta Yayınları.

Hayes, C. J. (1995). Milliyetçilik: Bir din. (Çev. Murat Çiftkaya).İstanbul: İz Yayınları.

Bruinessen, V. M. (2008). A $\breve{g} a$ şeyh devlet. İstanbul: İletişim.

Bruinessen, V. M. (2010). Kürdistan üzerine yazılar. (Çev. N. Kıraç, B. Peker, L. Keskiner, H. Turansal, S. Somuncuoğlu ve L. Kafadar), İstanbul: İletişim.

Çiçek, C. (2015). Ulus, din, sımıf, Türkiye'de kürt mutabakatının inşası. İstanbul: İletişim Yayınları.

Davison, A. (2012). Türkiye'de sekülerizm ve modernlik. (Çev. T. Birkan).İstanbul: İletişim Yayınları.

Gellner, E. (2013). Uluslar ve ulusçuluk.(Çev. B. Ersanlı, G. G. Özdoğan). İstanbul: Hil Yayınları.

Greenfeld, L. (2017). Milliyetçilik, moderniteye giden bes, yol: Ingiltere, Fransa, Almanya, Rusya, Amerika.(Çev. Abdullah Yılmaz). İstanbul: Alfa Yayınları.

Hobsbawm, E. J. (1995), 1780'den gü̈ü̈ü̈e milletler ve milliyetçilik.(Çev. Osman Akınhay). İstanbul: Ayrıntı Yayınları.

Kellas, J. G. (1991). The politics of nationalism and ethnicity. London: Macmillan. 
Keskin, N. B. (2016). Cumhuriyet döneminde milliyetçi düşüncede dini dönüşümler: Ziya Gökalp ve Erol Güngör ekseninde bir değerlendirme. İLEM içinde, III. Türkiye Lisansüstü Çalışmalar Kongresi Bildiriler Kitabı $I$, s.24-39.

Kodaman, B. (1987), Sultan II. Abdülhamid devri Doğu Anadolu politikası.Ankara: Türk Kültürü Araştırma Enstitüsü Yayınları.

Lewis, B. (1993). Modern Türkiye'nin doğuşu.(Çev. M. Kıratlı). İstanbul: Türk Tarih Kurumu Yayınları.

Llobera, R. J. (2007), Modernligin tanrısı Batı Avrupa'da Milliyetçiliğ̌n geliş̧imi. (Çev. Emek Akman-Ebru Akman).Ankara: Phoenix Yayınevi.

Maalouf, A. (2008). Ölümcül kimlikler.(Çev. A. Bora). İstanbul: Yapı Kredi Yayınları.

Mardin, Ş. (1993). Din ve ideoloji. İstanbul: İletişim Yayınları.

Öğün, S. S. (2000). Mukayeseli Sosyal Teori ve tarih bağlamında Milliyetçilik. İstanbul: Alfa Yayınları.

Sancaktar, C. (2019). Sosyalist Yugoslavya'nın yıkılışında hırvat milliyetçiliğinin rolü. Akademik İncelemeler Dergisi, 14(1), 51-86.

Smith, A. D. (1994). Milli kimlik. (Çev. B. Şener). İstanbul: İletişim Yayınları.

Şimşir, B. N. (2009). Bulgaristan Türkleri. İstanbul: Bilgi Yayınevi

Yalçıner, R. (2014). Etnisite ve Milliyetçilik: eles,tirel bir degerlendirme. Ankara Universitesi Sosyal Bilimler Fakultesi Dergisi,69(1),189-215.

Taylor, C. (2014). Seküler çă̆.(Çev. D. Körpe). İstanbul: Türkiye İş Bankası Yayinları.

Todorov, N. (1979). Bulgaristan tarihi.(Çev. V. Ataman). İstanbul: Öncü Yayınları.

\section{Kaynakça Bilgisi / Citation Information}

Kökce, H. (2021). Din ve milliyetçik ilişkisi: Kolaylaştırıcı mı zorlaştırıcı mı?. OPUS-Uluslararası Toplum Araştırmaları Dergisi, 18(40), 27752796. DOI: $10.26466 /$ opus. 864887. 